\title{
Occupational exposure to bisphenol-A (BPA) and the risk of Self-Reported Male Sexual Dysfunction
}

\section{D. $\mathrm{Li}^{1,7}$, Z. Zhou ${ }^{2}$, D. Qing ${ }^{3}$, Y. $\mathrm{He}^{2}$, T. Wu ${ }^{2}$, M. Miao ${ }^{3}$, J. Wang ${ }^{4}$, X. Weng', J.R. Ferber', L.J. Herrinton', Q. Zhu' ${ }^{3,5}$, E. Gao ${ }^{3,5}$, H. Checkoway', and W. Yuan ${ }^{3,5}$}

\begin{abstract}
'Division of Research, Kaiser Foundation Research Institute,Kaiser Permanente Northern California, 2000 Broadway, Oakland, CA 946I2, USA ${ }^{2}$ Department of Occupational Health and Toxicology, School of Public Health and WHO Collaborating Center for Occupational Health, Fudan University, Shanghai, China ${ }^{3}$ Shanghai Institute of Planned Parenthood Research, 2140 Xie Tu Road, Shanghai 200032, China 75 ${ }^{4}$ Epidemiology Department, Shanxi Medical University, 56 Xin Jian Nan Road, Taiyuan 03000I, PR China ${ }^{5}$ National Population and Family Planning Key Laboratory of Contraceptive Drugs and Devices, Shanghai, 2140 Xie Tu Road, Shanghai 200032, China ${ }^{6}$ Department of Environmental Health, University of Washington, Seattle, WA 98195, USA

${ }^{7}$ Correspondence address. Division of Research, Kaiser Permanente Northern California, 2000 Broadway, Oakland, CA 946।2, USA. E-mail: dkl@dor.kaiser.org
\end{abstract}

BACKGROUND: Animal studies have suggested that bisphenol-A (BPA) is a potential human endocrine disrupter; but evidence from human studies is needed.

METHODS: We conducted an occupational cohort study to examine the effect of occupational exposure to BPA on the risk of male sexual dysfunction. Current workers from BPA-exposed and control factories were recruited. The exposed workers were exposed to very high BPA levels in their workplace. Male sexual function was ascertained through in-person interviews using a standard male sexual function inventory.

RESULTS: BPA-exposed workers had consistently higher risk of male sexual dysfunction across all domains of male sexual function than the unexposed workers. After controlling for matching variables and potential confounders, exposed workers had a significantly increased risk of reduced sexual desire [odds ratios $(O R)=3.9,95 \%$ confidence interval: $1.8-8.6)$, erectile difficulty $(\mathrm{OR}=4.5,95 \% \mathrm{Cl} 2.1-9.8)$, ejaculation difficulty $(\mathrm{OR}=7.1,95 \% \mathrm{Cl} 2.9-17.6)$, and reduced satisfaction with sex life $(\mathrm{OR}=3.9,95 \% \mathrm{Cl} 2.3-6.6)$. A dose-response relationship was observed with an increasing level of cumulative BPA exposure associated with a higher risk of sexual dysfunction. Furthermore, compared with the unexposed workers, BPA-exposed workers reported significantly higher frequencies of reduced sexual function within I year of employment in the BPA-exposed factories.

CONCLUSIONS: Our findings provide the first evidence that exposure to BPA in the workplace could have an adverse effect on male sexual dysfunction.

Key words: bisphenol-A / epidemiology / occupational studies / cohort study

Similar to diethylstilbestrol (DES), bisphenol-A (BPA) was first recognized in the 1930s to be a potential synthetic estrogen (Dodds and Lawson, 1938). However, unlike DES that was eventually selected for medicinal use and later discovered to be a carcinogen and to cause many other health problems (Giusti et al., 1995; Swan, 2000; Klip et al., 2002; Palmer et al., 2006; Troisi et al., 2007), BPA found its way into plastic production, mainly in the production of polycarbonated plastics and epoxy resins. BPA is contained in many consumer products including baby bottles, plastic containers and the resin lining of cans used for food and beverages, as well as dental sealants (National Toxicology Program, 2008). Use of polycarbonate bottles has been shown to lead to increased urine BPA levels (Carwile et al., 2009). Most human popu- 105 lation could be constantly exposed to some levels of BPA. In a national sample of the US population, more than $90 \%$ of spot urine samples had detectable BPA with a median urine level of $2.7 \mu \mathrm{g} / \mathrm{l}$ (Calafat et al., 2005; Calafat et al., 2008; National Toxicology Program, 2008). Since BPA has a fast metabolism rate (half-life time $<6 \mathrm{~h}$ ) (National Toxi- 110 cology Program, 2008), this finding suggests a continuous exposure to

(C) The Author 2009. Published by Oxford University Press on behalf of the European Society of Human Reproduction and Embryology. All rights reserved. For Permissions, please email: journals.permissions@oxfordjournals.org 
115 BPA in the US population. Similar findings of BPA exposure have been reported in other countries as well (Kim et al., 2003; Matsumoto et al., 2003; Miyamoto and Kotake, 2006).

Animal studies have shown that BPA affects the male reproductive system including androgen receptors (ARs), male sex hormone levels, male reproductive organs including testes, epididymis, sperm and seminal vesicles, the prostate gland and sperm production (Richter et al., 2007; National Toxicology Program, 2008). Changes in sexual behavior including a reduced performance in latency and frequency of intromission among rodents that had been exposed to BPA have

125 also been reported (Farabollini et al., 2002; Della et al., 2006; Richter et al., 2007). BPA has been shown to have both estrogenic and antiandrogenic effects in both in vivo and in vitro studies (Sohoni and Sumpter, 1998; Lee et al., 2003; Xu et al.,2005; Sun et al., 2006; Wetherill et al., 2007; National Toxicology Program, 2008).

130 Nonetheless, some researchers have not observed any effects of BPA in their animal studies (Tyl et al., 2002; Tyl et al., 2008a, b). However, these findings of a lack of an observed BPA effect have been recently challenged by a group of scientists from more than 30 academic and research institutes (Myers et al., 2009).

135 BPA has been considered a highly suspect human endocrine disruptor, likely affecting both male and female reproductive systems. However, the evidence of such effects of BPA from epidemiological studies of the human population remain lacking as noted by two US government panels convened by the National Toxicology Program

140 and the National Institute of Environmental Health and Safety (Kuehn, 2007; vom Saal et al., 2007; National Toxicology Program, 2008), respectively. Largely based on findings from animal studies, these two panels reached somewhat different conclusions on the potential effect of BPA as a human endocrine disruptor, leading to a after the recent tentative decision on BPA safety by the Food and Drug Administration (FDA) in the USA (http://www.fda.gov/oc/ opacom/hottopics/bpa.html) was subsequently rebutted by its own Science Board (http://www.time.com/time/health/article/0,8599, I50 |855853,00.html).

We have conducted an occupational cohort study to evaluate whether exposure to high levels of BPA affects male sexual functioning. Given its reported antiandrogenic and estrogenic effects and observed adverse effects on sexual behaviors and the male reproducsexual dysfunction may be a sensitive endpoint not only relevant to male fertility, but also to other endpoints on which the effect is not as easily detected.

\section{Materials and Methods}

From 2004 to 2008, we conducted an occupational cohort study among workers of manufacturers of BPA and epoxy resin in China where rela-

tively high exposure to BPA could be observed. Epoxy resin manufacturers use BPA as one of their raw materials. We collaborated with two Chinese academic and research institutions which were responsible for data collection for the study. The same data collection protocols were used for both the exposed and unexposed factories. The study was presented to all participating factories (both exposed and unexposed) as a study of health study was approved by the Institutional Review Boards of all three participating institutes, and all participants signed an informed consent form before participation in the study.

\section{Exposed workers}

In one participating BPA manufacturer and three epoxy resin manufacturers, all workers with exposure to BPA were eligible for the study. This included workers in the manufacturing process, packaging, technical supervisors, laboratory technicians, and maintenance workers. Among 373 eligible male workers, $230(62 \%)$ agreed to participate in the study. Because current sexual function was ascertained, those who had left the factories $(n=46)$ were excluded, since current BPA exposure for those retired workers was likely low, therefore not reflective of their previous exposure at work. In addition, it is unknown at this time whether the effect of BPA on sexual dysfunction is reversible after an extended period of absence of exposure. Inclusion of those retired workers would have likely led to misclassification of their exposure level based on their past exposure only.

\section{Unexposed workers}

In the same city where the BPA-exposed workers were recruited, we identified unexposed control factories where no known occupational exposure to BPA existed. The selection of control factories were based on the following factors. First, the factories were from the same jurisdiction of the health department overseeing the occupational health of the participating BPA-exposed factory. Second, the factories had no known BPA exposure in the workplace. Third, the factories had workers who met the selection criteria for age, education, gender and employment history. Fourth, the owners of the factories agreed to participate in the study. Fifth, the factories were not exposed to known reproductive toxicants. To have better representation, the control factories came from a variety of industries including construction material manufacturers, water supply factories, machinery factories, garment factories, a textile factory, manufacturers of electronics, machinery factories, fire stations and trade and commerce firms. Unexposed workers were matched to exposed workers on age ( 5 year interval), gender, educational level and length of employment. Among 515 identified eligible unexposed male controls, $284(55 \%)$ agreed to participate in the study. To increase the sample size, we also included 120 male spouses whose wives were selected as unexposed controls for the BPA-exposed female workers. A total of 404 unexposed controls were available for analyses.

\section{BPA measurement}

For each of the four participating BPA-exposed factories, we conducted spot air sampling for each position in the manufacturing process, and personal air sample monitoring for each workplace with similar exposure levels. To determine workplaces with similar exposure, we collected exposure information according to the following steps. First, we thoroughly reviewed the factory's historical records including production capacity, remodelling history, and implementation of preventive measures. Second, we interviewed factory leaders and long-term workers about the history of BPA exposure to verify and supplement the information obtained from historical records. Third, our research team conducted a walk-through evaluation of each facility to determine the nature of BPA exposure and existence and utility of any preventive equipment. Fourth, we conducted in-person interviews with all participants to ascertain information on jobs held including start and end dates, changes of workplace and job titles, personal hygiene habits and use of protective equipment and exposures to other chemicals.

On the basis of the information obtained during these four steps, workplaces in each factory were categorized into subgroups with similar BPA 


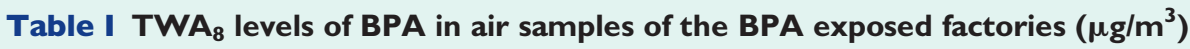

\begin{tabular}{|c|c|c|c|c|c|}
\hline Job title & Number of samples measured & Detectable rate & Median & Geometric mean & Percentile (25th-75th) \\
\hline Packaging & 18 & 0.94 & 8.18 & 15.67 & $2.53-299.65$ \\
\hline Chemical reaction & 67 & 0.96 & 2.16 & 4.1 & $0.85-11.00$ \\
\hline Material feeding & 17 & 0.88 & $|5.3|$ & 4.35 & $0.47-26.40$ \\
\hline Multitasking & 63 & 0.87 & 4.88 & 8.33 & $3.35-17.67$ \\
\hline Other* & 15 & 0.93 & 4.49 & 3.52 & I.74-5.73 \\
\hline Total average & 180 & 0.92 & 4.57 & 5.97 & $1.46-16.30$ \\
\hline
\end{tabular}

*Includes laboratory test, storage, administration and mechanical maintenance.

exposure levels. Personal air sample monitoring was carried out for all subgroups of BPA exposure workplaces so that we would have BPA exposure levels from personal air sample monitoring for each subgroup. The personal ir sample monitoring was carried out for the entire shift. We used the ESCORT ELF sampling pump with an inhalable fraction sampling head placed near the workers' inhalation level. Samples were collected at $2.0 \mathrm{I} /$ min using glass fiber filters. The BPA content from personal sampling was analysed by high-performance liquid chromatography with its limit of deteclated using the Time-weighted Average $\left(T_{W} A_{8}\right.$ ) for each individual who carried out the personal sample monitoring. $\mathrm{TWA}_{8}$ for a given BPA-exposed subgroup was the average of all individual TWAs 8 in this workplace. Table I presents the results of BPA exposure levels at various workplaces in the BPA exposed factories. In addition, spot urine BPA levels in sub-samples of the BPA-exposed and -unexposed workers who provided urine specimens clearly showed that BPA exposed workers had much higher urine BPA levels than unexposed workers (Table II).

BPA exposure levels for participants were measured by a cumulative exposure index (CEI). CEI was calculated as follows: $\mathrm{CEI}=\sum_{i=1}^{n} D_{i} \times \mathrm{TWA}_{8} i$ where $D_{i}$ was the work duration (years) in a given workplace (a BPA-exposed subgroup) and TWA ${ }_{8} i$ was the BPA exposure level in that workplace during the period. For current workers, we used $\mathrm{TWA}_{8}\left(\mu \mathrm{g} / \mathrm{m}^{3}\right)$ obtained through personal monitoring. For positions held in the past, we used TWA ${ }_{8}$ obtained from the records of historical monitoring data. For those who had personal monitoring, we used their own personal TWA $A_{8}$. For those who did not have personal TWA $A_{8}$, we used the average $\mathrm{TWA}_{8}$ for their job titles obtained from average personal monitoring of other workers with the same job titles in the same workplaces.

\section{Outcome measurement}

During an in-person interview in which we asked various questions regarding their demographic characteristics, work history, medical history, personal behaviors and sexual activities, we used The International Index of Erectile Function and the Brief Male Sexual Function Inventory (O'Leary et al., 1995; Rosen et al., 1997) to ascertain sexual functioning among par. Four domains of sexual function were ascertained: sexual desire, erectile function, orgasmic function and overall satisfaction with sex life. We excluded 20 exposed workers and 18 control workers who did not answer questions regarding sexual function largely due to a lack of sexual activities. In addition to current sexual function, we ascertained changes in sexual function (increase or decrease in sexual functions) since participants joined the BPA-exposed factories and corresponding unexposed factories to determine the timing of the impact of exposure to BPA on sexual function. The periods ascertained were I year or less after employment, $2-5$ years and greater than 5 years. Because very few participants reported increases in sexual function after employment, we combined those who reported an increase with those who reported

\begin{tabular}{|c|c|c|c|}
\hline \multirow[t]{2}{*}{ Occupational exposure to BPA** } & \multirow[t]{2}{*}{$n$} & \multicolumn{2}{|c|}{ Percentiles } \\
\hline & & 50th & 25th-75th \\
\hline No & 254 & 1.2 & $0-11$ \\
\hline Yes*** & 123 & 57.9 & $13-467$ \\
\hline
\end{tabular}

*Creatinine-corrected $(\mu \mathrm{g} / \mathrm{gCr})$.

**A subset of workers who provided urine samples.

***Pre-shift urine samples.

no change in sexual function. Therefore, the focus of the analysis was the frequency of decrease in sexual function. Those who did not have sexual activities during a given period (e.g. the first year of employment) were considered as missing from the analyses for this period.

Information on potential confounders were also ascertained during the in-person interview, including (i) demographic characteristics, (ii) factors that may influence sexual function including smoking, alcohol use, presence of chronic diseases and exposure to other chemicals and heavy metals, (iii) occupational history and (iv) sexual history.

\section{Analyses}

We employed the odds ratio (OR) and its $95 \%$ confidence interval $(\mathrm{Cl})$ to measure the association between exposure to BPA and the risk of male sexual dysfunction. We used logistic regression to estimate $O R$ of male 325 sexual dysfunction associated with BPA exposure after adjustment for potential confounders. The adjusted variables were chosen based on whether they were risk factors for male sexual dysfunction (e.g. age, smoking status, chronic diseases, etc.) or whether they impacted the estimated association between BPA exposure and the risk of male sexual dysfunction. SAS software was used to conduct the analyses.

\section{Results}

The BPA-exposed and -unexposed workers were comparable regard- 335 ing many demographic characteristics (e.g. age, marital status, etc.), their history of chronic diseases that may affect sexual function, and smoking and alcohol-drinking habits (Table III). When compared with the unexposed workers, BPA-exposed workers were less likely to have a college degree and more likely to have a history of exposure 340 to other chemicals. BPA-exposed workers had a slightly shorter employment history. 
Table III Characteristics of BPA-exposed and -unexposed workers

\begin{tabular}{|c|c|c|c|}
\hline Characteristics & Category & Unexposed $\left(n=386^{\prime}\right)(\%)$ & Exposed $\left(n=164^{1}\right)(\%)$ \\
\hline Age & $\begin{array}{l}\leq 25 \\
25-30 \\
30-35 \\
35-40 \\
40-45 \\
>45\end{array}$ & $\begin{array}{l}29(7.5) \\
66(17.1) \\
96(24.9) \\
83(21.5) \\
44(11.4) \\
68(17.6)\end{array}$ & $\begin{array}{c}8(4.9) \\
41(25.0) \\
32(19.5) \\
31(18.9) \\
22(13.4) \\
30(18.3)\end{array}$ \\
\hline Education & $\begin{array}{l}\leq \text { Junior high } \\
\text { Senior high } \\
\geq \text { College }\end{array}$ & $\begin{array}{r}\text { II } 2(29.1) \\
\text { I } 82(47.3) \\
91(23.6)\end{array}$ & $\begin{array}{l}62(37.8) \\
89(54.3) \\
13(7.9)\end{array}$ \\
\hline Married & $\begin{array}{l}\text { No } \\
\text { Yes }\end{array}$ & $\begin{array}{r}44(11.4) \\
342(88.6)\end{array}$ & $\begin{array}{r}20(12.2) \\
144(87.8)\end{array}$ \\
\hline Employment history (year) & $\begin{array}{l}<1 \\
l-5 \\
\geq 5\end{array}$ & $\begin{array}{c}28(7.3) \\
8 I(2 I . I) \\
275(7 \mid .6)\end{array}$ & $\begin{array}{l}22(13.4) \\
50(30.5) \\
92(56.1)\end{array}$ \\
\hline History of chronic disease ${ }^{2}$ & $\begin{array}{l}\text { No } \\
\text { Yes }\end{array}$ & $\begin{array}{r}308(79.8) \\
78(20.2)\end{array}$ & $\begin{array}{r}132(80.5) \\
32(19.5)\end{array}$ \\
\hline Ever exposed to other chemicals or heavy metals ${ }^{3}$ & $\begin{array}{l}\text { No } \\
\text { Yes }\end{array}$ & $\begin{array}{r}335(86.8) \\
51(13.2)\end{array}$ & $\begin{array}{l}68(4 \mid .5) \\
96(58.5)\end{array}$ \\
\hline Current smoker & $\begin{array}{l}\text { No } \\
\text { Yes }\end{array}$ & $\begin{array}{l}118(30.6) \\
268(69.4)\end{array}$ & $\begin{array}{r}59(36.0) \\
105(64.0)\end{array}$ \\
\hline History of alcohol intake & $\begin{array}{l}\text { No } \\
\text { Yes }\end{array}$ & $\begin{array}{l}279(72.3) \\
107(27.7)\end{array}$ & $\begin{array}{r}112(68.3) \\
52(31.7)\end{array}$ \\
\hline
\end{tabular}

'The number in each category may not match the total number due to missing values.

${ }^{2}$ Diseases that may impact male sexual function including urogenital diseases, autoimmune diseases, endocrine disorders, hypertension and other cardiovascular diseases, kidney diseases and injury to genital organs.

${ }^{3}$ Includes organic solvents, pesticides/herbicides and heavy metals (e.g. lead, mercury, etc.).

After adjustment for potential confounders including age, education, marital status, current smoking status, a history of chronic diseases and exposure to other chemicals, and employment history, the BPA-exposed workers had a significantly higher risk of sexual dysfunction among all indices measuring male sexual function in four domains (sexual desire, erectile function, orgasmic function and overall satisfaction with sex life), compared with the unexposed workers (Table IV).

exposed workers had a nearly 4 -fold increased risk of reduced sexual desire $(O R=3.9,95 \% \mathrm{Cl} \quad$ I.8-8.6), greater than 4-fold increased risk of erection difficulty associated with BPA exposure $(O R=4.5,95 \% \mathrm{Cl} 2.1-9.8)$, more than 7-fold increased risk of ejaculation difficulty $(\mathrm{OR}=7.1,95 \% \mathrm{Cl} 2.9-17.6)$ and almost 4 -fold increased risk of reduced overall satisfaction with sex life $(O R=3.9$, 95\% Cl 2.3-6.6) (Table IV).

To examine the dose-response relationship, we used CEI to measure the amount of cumulative BPA exposure for each exposed worker. We divided the CEl level into tertiles. A dose-

390 response relationship between a BPA cumulative exposure level and the risk of male sexual dysfunction was generally observed with increasing BPA exposure level being associated with greater risk of male sexual dysfunction except for the measure of sex desire (Table $\mathrm{V}$ ), providing additional support for an underlying association between BPA exposure and the risk of male sexual dysfunction.

To assess the length of time that it took for BPA exposure to have an effect on the risk of male sexual dysfunction, we examined the changes in male sexual function in relation to the duration of employment. When employment in a BPA-exposed factory lasted I year or less, BPA-exposed workers already experienced a significantly higher frequency of reduced sexual function compared with unexposed workers during the same period of employment. The BPA-exposed workers had more than 6-fold increased risk of having a reduction in frequency of intercourse $(O R=6.7)$ and ejaculation function $(O R=6.3)$, a 10 -fold increased risk of having reduced satisfaction with sex life $(O R=10.0)$, more than 17-fold increased risk of having reduced sex drive $(O R=17.7)$, and a 15 -fold increased risk of reduced ability to have an erection $(\mathrm{OR}=15.0)$ (Table $\mathrm{VI})$. Additional years of employment showed similar results.

To remove the potential interference of exposure to other chemicals, we conducted additional analyses after excluding those who had a history of exposure to other chemicals or heavy metals. The above observed associations between BPA exposure and the risk of male sexual dysfunction remained (Table VII).

\section{Discussion}

After the recent evaluation by the two US government-convened panels and the controversy between the FDA and its own Science Board, the question of the adverse effect of exposure to BPA on human health has raised substantial concern among the public because of widespread presence of BPA in the environment and in consumer products such as baby bottles and food and water containers (Kuehn, 2007; vom Saal et al.,2007; National Toxicology Program, 
Table IV Exposure to BPA and the risk of male sexual dysfunction

\begin{tabular}{|c|c|c|c|c|c|}
\hline Sexual function in the past 6 months & Category & Unexposed' & Exposed' & $O R^{2}(95 \% \mathrm{Cl})$ & $\mathrm{aOR}^{3}(95 \% \mathrm{Cl})$ \\
\hline \multicolumn{6}{|l|}{ Erectile function } \\
\hline Ability to have an erection & $\begin{array}{l}\text { Usually ( } \geq 50 \% \text { of time) } \\
\text { Not usually }(<50 \%)\end{array}$ & $\begin{array}{c}368(95.6) \\
17(4.4)\end{array}$ & $\begin{array}{r}136(84.5) \\
25(15.5)\end{array}$ & $\begin{array}{l}\text { Reference } \\
\mathbf{4 . 0}(2.1-7.6)\end{array}$ & $\begin{array}{l}\text { Reference } \\
\mathbf{3 . 9}(1.8-8.5)\end{array}$ \\
\hline Ability to have an erection hard enough for penetration & $\begin{array}{l}\text { Usually ( } \geq 50 \% \text { of time) } \\
\text { Not usually }(<50 \%)\end{array}$ & $\begin{array}{r}361(94.0) \\
23(6.0)\end{array}$ & $\begin{array}{r}132(82.0) \\
29(18.0)\end{array}$ & $\begin{array}{l}\text { Reference } \\
\mathbf{3 . 4}(1.9-6.2)\end{array}$ & $\begin{array}{l}\text { Reference } \\
\mathbf{3 . 8}(1.9-7.6)\end{array}$ \\
\hline Difficulty of having an erection & $\begin{array}{l}\text { No difficulty } \\
\text { Some difficulties }\end{array}$ & $\begin{array}{l}365(96.1) \\
15(3.9)\end{array}$ & $\begin{array}{r}135(84.4) \\
25(15.6)\end{array}$ & $\begin{array}{l}\text { Reference } \\
\mathbf{4 . 5}(2.3-8.8)\end{array}$ & $\begin{array}{l}\text { Reference } \\
4.5(2.1-9.8)\end{array}$ \\
\hline \multicolumn{6}{|l|}{ Orgasmic function } \\
\hline Difficulty level of ejaculating & $\begin{array}{l}\text { No difficulty } \\
\text { Some difficulties }\end{array}$ & $\begin{aligned} 349 & (97.5) \\
9 & (2.5)\end{aligned}$ & $\begin{array}{r}136(86.1) \\
22(13.9)\end{array}$ & $\begin{array}{l}\text { Reference } \\
\mathbf{6 . 3}(2.8-14.0)\end{array}$ & $\begin{array}{l}\text { Reference } \\
\mathbf{7 . 1}(2.9-17.6)\end{array}$ \\
\hline Level of ejaculation strength $(0-10)$ & $\begin{array}{l}10 \\
0-9\end{array}$ & $\begin{array}{r}300(84.3) \\
56(15.7)\end{array}$ & $\begin{array}{l}90(57.0) \\
68(43.0)\end{array}$ & $\begin{array}{l}\text { Reference } \\
\mathbf{4 . 0}(2.6-6.2)\end{array}$ & $\begin{array}{l}\text { Reference } \\
\mathbf{3 . 5}(2.1-5.7)\end{array}$ \\
\hline \multicolumn{6}{|l|}{ Sexual desire } \\
\hline Level of sex drive $(0-10)$ & $\begin{array}{l}>5 \\
0-5\end{array}$ & $\begin{array}{l}369(95.8) \\
16(4.2)\end{array}$ & $\begin{array}{r}140(87.0) \\
2 \mid(13.0)\end{array}$ & $\begin{array}{l}\text { Reference } \\
\mathbf{3 . 5}(1.8-6.8)\end{array}$ & $\begin{array}{l}\text { Reference } \\
3.9(1.8-8.6)\end{array}$ \\
\hline \multicolumn{6}{|l|}{ Overall satisfaction with sex life } \\
\hline Level of satisfaction $(0-10)$ & $\begin{array}{l}10 \\
0-9\end{array}$ & $\begin{array}{r}305(86.2) \\
49(13.8)\end{array}$ & $\begin{array}{l}95(61.3) \\
60(38.7)\end{array}$ & $\begin{array}{l}\text { Reference } \\
3.9(2.5-6.1)\end{array}$ & $\begin{array}{l}\text { Reference } \\
\mathbf{3 . 9}(2.3-6.6)\end{array}$ \\
\hline
\end{tabular}

2008). Therefore, studies of the effect of BPA on humans are critically needed to help establish prevention strategies and regulatory policies.

The results from the current study provide important evidence that exposure to BPA in the workplace significantly increases the risk of male sexual dysfunction. The finding was consistent for all four domains measuring male sexual dysfunction, all showing elevated risks associated with BPA exposure. The magnitude of the risk associated with BPA exposure was quite significant as well, ranging from more than 3-fold to more than 7-fold increased risk. The observed associations remained after controlling for many physiological and behavioral factors that may be related to sexual dysfunction between BPA-exposure and -unexposed workers. In addition, the doseresponse relationship for observed associations further strengthens the findings. The combination of these findings supports a likely underlying link between exposure to high BPA levels and increased risk of male sexual dysfunction in the human population.

Furthermore, we also examined changes in workers' sexual function since they were first exposed to BPA in the workplace. Such a measure of change in sexual function in relation to the timing of exposure and the subsequent evidence of a significant reduction in sexual function after their employment in a BPA-exposed factory compared with the similar, but unexposed, workers provides additional support for a possible detrimental effect of BPA on the risk of male sexual dysfunction.

Both in vitro and in vivo experimental studies have provided consistent evidence to support our findings that BPA exposure increases the risk of male sexual dysfunction. The BPA effect in animal studies has been observed at low-dose levels similar to current human environmental exposure levels (Richter et al., 2007). While sexual dysfunction in animal studies is difficult to conduct, several studies have reported changes of sexual behavior including a reduced performance in latency and frequency of intromission among rodents that were exposed to BPA (Farabollini et al., 2002; Della et al., 2006; Richter et al., 2007). In addition to the consistent evidence from the animal studies of the effect of BPA on the risk of sexual dysfunction, both 545 in vitro and in vivo studies have provided evidence of underlying mechanisms for the observed association, including the effects of BPA on the ARs, on male sex hormone levels, on male reproductive organs including testes, epididymis, sperm and seminal vesicles, and prostate gland, and on sperm production (Richter et al., 2007; National Toxi- 550 cology Program, 2008). BPA has been reported to have both estrogenic and antiandrogenic effects (Sohoni and Sumpter, 1998; Lee et al., 2003; Xu et al., 2005; Sun et al., 2006; Bonefeld-Jorgensen et al., 2007; Richter et al., 2007; Wetherill et al.,2007; National Toxicology Program, 2008). BPA has been shown to act as an AR antag- 555 onist that interrupts normal AR binding activity and therefore the interaction between $A R$ and endogenous androgens (Wetherill et al., 2007). Such an interruption to the function of endogenous androgens by BPA could disturb normal male sexual functions including libido and erectile and orgasmic functions. In addition, BPA has 560 been reported to interfere with the function of Leydig cells resulting in a reduction of testosterone biosynthesis (Akingbemi et al., 2004) and to adversely affect several tissue and cell structures of male sex organs through various mechanisms including possible epigenetic effects (Richter et al., 2007; Wetherill et al., 2007). Therefore, our 565 observed association between BPA exposure and the risk of male sexual dysfunction is biologically plausible and well supported by experimental studies.

We evaluated the potential existence of participation bias in our results by examining whether participants and non-participants had 570 
Table V Dose-response relationship of the effect of exposure to BPA on the risk of male sexual dysfunction

\begin{tabular}{|c|c|c|c|c|c|c|c|c|c|}
\hline $\begin{array}{l}\text { Sexual function in the past } 6 \\
\text { months }\end{array}$ & Category & Unexposed ${ }^{1}$ & $\begin{array}{l}\text { Exposed' CEI } \\
\text { tertile I }\end{array}$ & $\begin{array}{l}\mathrm{aOR}^{2}(95 \% \\
\mathrm{Cl})\end{array}$ & $\begin{array}{l}\text { Exposed' CEI } \\
\text { tertile } 2\end{array}$ & $\begin{array}{l}\mathrm{aOR}^{2}(95 \% \\
\mathrm{Cl})\end{array}$ & $\begin{array}{l}\text { Exposed' CEI } \\
\text { tertile } 3\end{array}$ & $\begin{array}{l}\mathrm{aOR}^{2}(95 \% \\
\mathrm{Cl})\end{array}$ & $\begin{array}{l}\text { Trend test } \\
P \text {-value }\end{array}$ \\
\hline \multicolumn{10}{|l|}{ Erectile function } \\
\hline \multirow[t]{2}{*}{ Ability to have an erection } & $\begin{array}{l}\text { Usually ( } \geq 50 \% \text { of } \\
\text { time) }\end{array}$ & $368(95.6)$ & $48(92.3)$ & Reference & $48(85.7)$ & Reference & $40(75.5)$ & Reference & \\
\hline & $\begin{array}{l}\text { Not usually } \\
(<50 \%)\end{array}$ & $17(4.4)$ & $4(7.7)$ & $2.3(0.7-8.0)$ & $8(14.3)$ & $3.5(1.3-9.2)$ & $13(24.5)$ & $\begin{array}{l}\mathbf{5 . 7}(2.3- \\
14.6)\end{array}$ & $<0.01$ \\
\hline \multirow[t]{2}{*}{$\begin{array}{l}\text { Ability to have an erection hard } \\
\text { enough for penetration }\end{array}$} & $\begin{array}{l}\text { Usually ( } \geq 50 \% \text { of } \\
\text { time) }\end{array}$ & $36 \mid(94.0)$ & $48(92.3)$ & Reference & $46(82.1)$ & Reference & $38(71.7)$ & Reference & \\
\hline & $\begin{array}{l}\text { Not usually } \\
(<50 \%)\end{array}$ & $23(6.0)$ & $4(7.7)$ & I.8 $(0.5-6.0)$ & $10(17.9)$ & $3.9(1.6-9.2)$ & $15(28.3)$ & $\begin{array}{l}\mathbf{5 . 4}(2.3- \\
12.5)\end{array}$ & $<0.01$ \\
\hline Difficulty of having an erection & $\begin{array}{l}\text { No difficulty } \\
\text { Some difficulties }\end{array}$ & $\begin{array}{l}365(96.1) \\
15(3.9)\end{array}$ & $\begin{array}{r}46(88.5) \\
6(11.5)\end{array}$ & $\begin{array}{l}\text { Reference } \\
\mathbf{4 . 9}(1.6- \\
\text { 15.5) }\end{array}$ & $\begin{array}{r}50(89.3) \\
6(10.7)\end{array}$ & $\begin{array}{l}\text { Reference } \\
\mathbf{3 . 0}(1.0-8.7)\end{array}$ & $\begin{array}{l}39(75.0) \\
13(25.0)\end{array}$ & $\begin{array}{l}\text { Reference } \\
\mathbf{6 . 2}(2.4- \\
\text { 15.8) }\end{array}$ & $<0.01$ \\
\hline \multicolumn{10}{|l|}{ Orgasmic function } \\
\hline Difficulty level of ejaculating & $\begin{array}{l}\text { No difficulty } \\
\text { Some difficulties }\end{array}$ & $\begin{aligned} 349(97.5) \\
9(2.5)\end{aligned}$ & $\begin{array}{c}47(92.2) \\
4(7.8)\end{array}$ & $\begin{array}{l}\text { Reference } \\
4.6(1.2- \\
\text { I7.8) }\end{array}$ & $\begin{array}{r}47(85.5) \\
8(14.6)\end{array}$ & $\begin{array}{l}\text { Reference } \\
\mathbf{7 . 3}(2.5- \\
21.4)\end{array}$ & $\begin{array}{l}42(80.8) \\
10(19.2)\end{array}$ & $\begin{array}{l}\text { Reference } \\
\mathbf{8 . 6}(2.9- \\
25.5)\end{array}$ & $<0.01$ \\
\hline $\begin{array}{l}\text { Level of ejaculation strength } \\
(0-10)\end{array}$ & $\begin{array}{l}10 \\
0-9\end{array}$ & $\begin{array}{r}300(84.3) \\
56(15.7)\end{array}$ & $\begin{array}{l}29(56.9) \\
22(43.1)\end{array}$ & $\begin{array}{l}\text { Reference } \\
\text { 4.I }(2.0-8.3)\end{array}$ & $\begin{array}{l}37(67.3) \\
18(32.7)\end{array}$ & $\begin{array}{l}\text { Reference } \\
\mathbf{2 . 3}(1.2-4.6)\end{array}$ & $\begin{array}{l}24(46.2) \\
28(53.9)\end{array}$ & $\begin{array}{l}\text { Reference } \\
\mathbf{4 . 7}(2.4-9.3)\end{array}$ & $<0.01$ \\
\hline \multicolumn{10}{|l|}{ Sexual desire } \\
\hline Level of sex drive $(0-10)$ & $\begin{array}{l}>5 \\
0-5\end{array}$ & $\begin{array}{l}369(95.8) \\
16(4.2)\end{array}$ & $\begin{array}{r}44(88.0) \\
6(12.0)\end{array}$ & $\begin{array}{l}\text { Reference } \\
\mathbf{5 . 0}(1.6- \\
\text { I5.7) }\end{array}$ & $\begin{array}{r}49(87.5) \\
7(12.5)\end{array}$ & $\begin{array}{l}\text { Reference } \\
\mathbf{3 . 7}(1.3- \\
10.4)\end{array}$ & $\begin{array}{r}47(85.5) \\
8(14.6)\end{array}$ & $\begin{array}{l}\text { Reference } \\
\mathbf{3 . 5}(1.2-9.8)\end{array}$ & $<0.01$ \\
\hline \multicolumn{10}{|l|}{ Overall satisfaction with sex life } \\
\hline Level of satisfaction $(0-10)$ & $\begin{array}{l}10 \\
0-9\end{array}$ & $\begin{array}{r}305(86.2) \\
49(13.8)\end{array}$ & $\begin{array}{l}35(68.6) \\
16(31.4)\end{array}$ & $\begin{array}{l}\text { Reference } \\
\mathbf{3 . 3}(1.5-7.0)\end{array}$ & $\begin{array}{l}36(66.7) \\
18(33.3)\end{array}$ & $\begin{array}{l}\text { Reference } \\
\mathbf{3 . 2}(1.6-6.4)\end{array}$ & $\begin{array}{l}24(48.0) \\
26(52.0)\end{array}$ & $\begin{array}{l}\text { Reference } \\
\mathbf{5 . 5}(2.7- \\
\text { II.2) }\end{array}$ & $<0.01$ \\
\hline
\end{tabular}


Table VI Exposure to BPA and changes in male sexual function

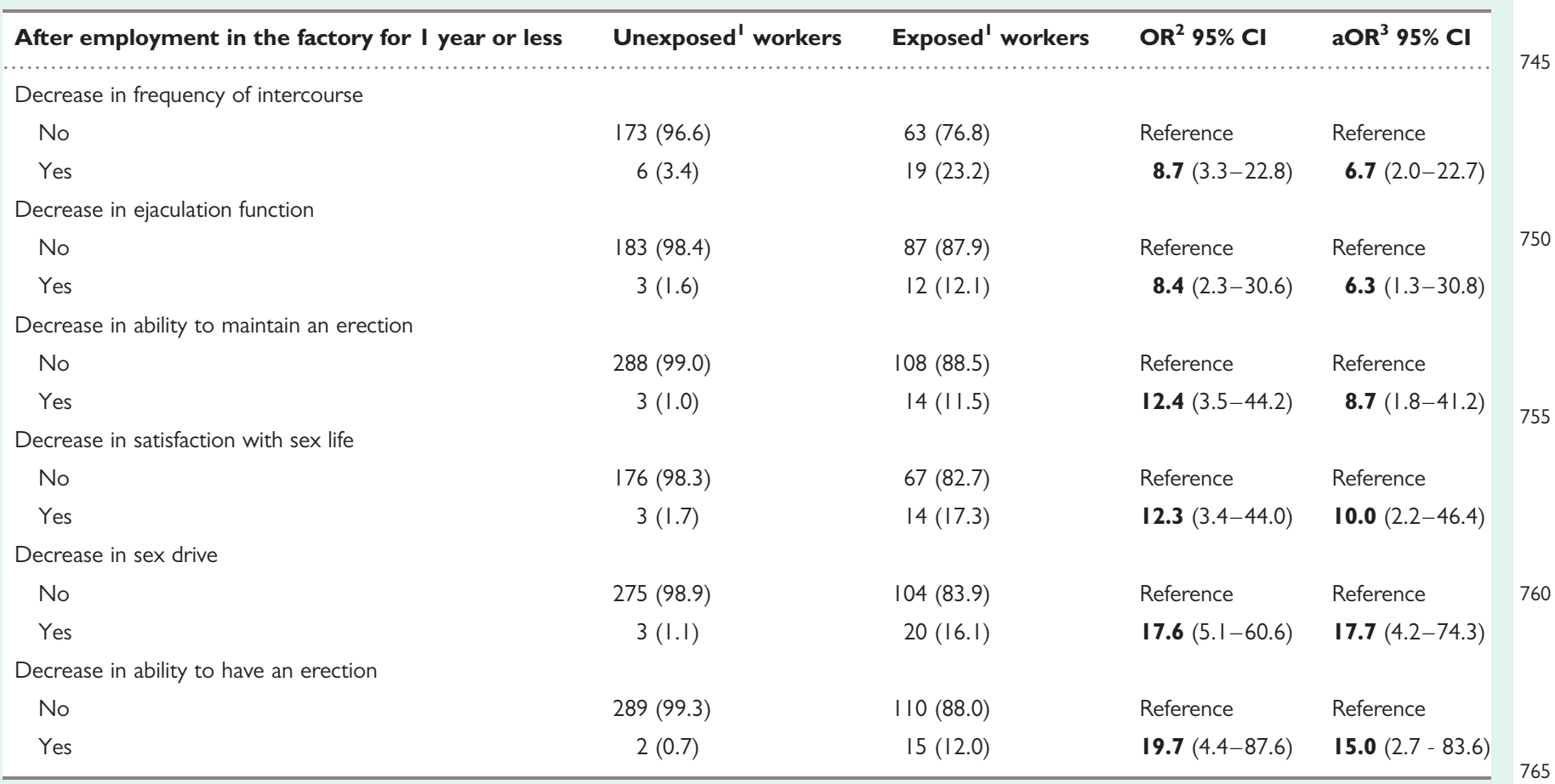

'The number in each category of sexual function may vary due to missing values or absence of sexual activities (N/A).

${ }^{2}$ Crude odds ratio.

${ }^{3} \mathrm{aOR}$ : adjusted odds ratio; $95 \% \mathrm{Cl}$ : confidence interval. Adjusted for age, education, marital status, current smoking status, a history of chronic diseases, exposure to other chemicals and occupational history.

Table VII Exposure to BPA and the risk of male sexual dysfunction among those without previous exposure to other chemicals or heavy metals

\begin{tabular}{|c|c|c|c|c|c|}
\hline Sexual function in the past 6 months & Category & Unexposed' & Exposed ${ }^{\prime}$ & $\mathrm{OR}^{2}(95 \% \mathrm{Cl})$ & $\mathrm{aOR}^{3}(95 \% \mathrm{Cl})$ \\
\hline \multicolumn{6}{|l|}{ Erectile function } \\
\hline Ability to have an erection & $\begin{array}{l}\text { Usually ( } \geq 50 \% \text { of time) } \\
\text { Not usually }(<50 \%)\end{array}$ & $\begin{array}{c}323(96.7) \\
\quad 11(3.3)\end{array}$ & $\begin{array}{l}53(79.1) \\
14(20.9)\end{array}$ & $\begin{array}{l}\text { Reference } \\
\mathbf{7 . 8}(3.3-\mid 8.0)\end{array}$ & $\begin{array}{l}\text { Reference } \\
\text { I0.6 }(4.0-28.0)\end{array}$ \\
\hline Ability to have an erection hard enough for penetration & $\begin{array}{l}\text { Usually ( } \geq 50 \% \text { of time) } \\
\text { Not usually }(<50 \%)\end{array}$ & $\begin{array}{c}317(95.2) \\
16(4.8)\end{array}$ & $\begin{array}{l}49(73.1) \\
18(26.9)\end{array}$ & $\begin{array}{l}\text { Reference } \\
\mathbf{7 . 3}(3.5-15.2)\end{array}$ & $\begin{array}{l}\text { Reference } \\
\mathbf{8 . 4}(3.6-19.6)\end{array}$ \\
\hline Difficulty of having an erection & $\begin{array}{l}\text { No difficulty } \\
\text { Some difficulties }\end{array}$ & $\begin{array}{l}319(96.4) \\
12(3.6)\end{array}$ & $\begin{array}{l}54(80.6) \\
13(19.4)\end{array}$ & $\begin{array}{l}\text { Reference } \\
\mathbf{6 . 4}(2.8-14.8)\end{array}$ & $\begin{array}{l}\text { Reference } \\
\mathbf{4 . 9}(2.0-1 \mid .8)\end{array}$ \\
\hline \multicolumn{6}{|l|}{ Orgasmic function } \\
\hline Difficulty level of ejaculating & $\begin{array}{l}\text { No difficulty } \\
\text { Some difficulties }\end{array}$ & $\begin{array}{c}305(97.8) \\
7(2.2)\end{array}$ & $\begin{array}{l}53(81.5) \\
12(18.5)\end{array}$ & $\begin{array}{l}\text { Reference } \\
\mathbf{9 . 9}(3.7-26.2)\end{array}$ & $\begin{array}{l}\text { Reference } \\
\mathbf{9 . 1}(3.2-25.7)\end{array}$ \\
\hline Level of ejaculation strength $(0-10)$ & $\begin{array}{l}10 \\
0-9\end{array}$ & $\begin{array}{r}266(85.8) \\
44(14.2)\end{array}$ & $\begin{array}{l}35(53.8) \\
30(46.2)\end{array}$ & $\begin{array}{l}\text { Reference } \\
\mathbf{5 . 2}(2.9-9.3)\end{array}$ & $\begin{array}{l}\text { Reference } \\
\mathbf{4 . 9}(2.7-9.1)\end{array}$ \\
\hline \multicolumn{6}{|l|}{ Sexual desire } \\
\hline Level of sex drive $(0-10)$ & $\begin{array}{l}>5 \\
0-5\end{array}$ & $\begin{array}{c}322(96.4) \\
12(3.6)\end{array}$ & $\begin{array}{l}56(82.4) \\
12(17.6)\end{array}$ & $\begin{array}{l}\text { Reference } \\
\mathbf{5 . 7}(2.5-13.4)\end{array}$ & $\begin{array}{l}\text { Reference } \\
\mathbf{6 . 0}(2.3-15.5)\end{array}$ \\
\hline \multicolumn{6}{|l|}{ Overall satisfaction with sex life } \\
\hline Level of satisfaction $(0-10)$ & $\begin{array}{l}10 \\
0-9\end{array}$ & $\begin{array}{r}269(87.3) \\
39(12.7)\end{array}$ & $\begin{array}{l}34(52.3) \\
31(47.7)\end{array}$ & $\begin{array}{l}\text { Reference } \\
\mathbf{6 . 3}(3.5-11.4)\end{array}$ & $\begin{array}{l}\text { Reference } \\
\mathbf{5 . 9}(3.1-\mid 1.1)\end{array}$ \\
\hline
\end{tabular}

'The number in each category of sexual function may vary due to missing values or absence of sexual activities (N/A).

${ }^{2}$ Crude odds ratio.

${ }^{3}$ aOR: adjusted odds ratio; $95 \% \mathrm{Cl}$ : confidence interval. Adjusted for age, education, marital status, current smoking status, presence of chronic diseases and occupational history. 
different risk profiles and whether participation patterns differed mation that was available for non-participants, we compared age and employment history between participants and non-participants and between the exposed and unexposed groups simultaneously. Nonparticipants were slightly older than participants and, consistent with

805 age, had slightly longer employment history than participants. However, this pattern of slight difference between participants and non-participants was similar between exposed and unexposed groups. Finally, the dose-response relationships shown in Table $\mathrm{V}$ do not support the argument for participation bias as an explanation

810 of our findings. While the instruments used in this study to ascertain sexual dysfunction have been used extensively in studies of human populations (O'Leary et al., 1995; Rosen et al., 1997), one may argue that self-reported sexual function may contain inaccuracies. Because neither the exposed nor unexposed workers were aware

815 of the specific underlying hypothesis of the study, it was unlikely that any misreporting would have been different between the exposed and unexposed workers. Therefore, any such non-differential misreporting of sexual dysfunction by participants would likely have led to attenuation of the observed association. In other words, without greater.

Another factor which could possibly impact self-reported sexual dysfunction, and hence the results of the study, is the levels of stress experienced by the exposed, compared with unexposed, workers. Although we did not collect information on stress from participants, there was no evidence that the exposed workers were in a more stressful work environment than the unexposed workers. In fact, a few of these exposed factories had more automated manufacturing processes which should make the working environmental less stressful.

We included 120 male spouses whose wives participated in the study as unexposed controls for exposed female workers to increase the sample size for the unexposed cohort. The reasons for including them were as follows: first, they were not exposed to BPA in the

835 workplace and second, they were measured in the same way as other participants in the study. Nevertheless, they were not matched to the exposed workers on age, educational levels and employment history, thus, the distribution on these variables were different from those in the exposed group, which led to the differing distributions of some characteristics in Table III. However, the information on these variables was collected, which allowed us to control for them in the multivariable analysis to achieve the same effect as the matching process. Therefore, our observed association between BPA exposure and the risk of male sexual dysfunction was 845 independent of these potential confounders. Finally, excluding these 120 and using only the originally selected controls produced essentially the same results.

The CEl used in measuring BPA exposure level in this study is likely to reflect the cumulative BPA exposure level. As showed in

850 Table II, the BPA exposure level in this occupationally exposed population was much higher than that of the non-occupationally exposed general population. Therefore, the findings from this study probably do not apply to populations that are exposed to low levels of BPA. In addition, the potential mechanisms of the such observational studies, unmeasured confounders remain a possible explanation for the observed association. Finally, for some new workers $(<10 \%)$, the exposure and outcomes were ascertained during relatively the same period. For them, the study could be considered as cross-sectional. However, for most participants, their BPA exposures were from periods before the outcome measurements.

In this occupational cohort study, we observed an increased risk of male sexual dysfunction associated with BPA exposure in the workplace. The observed association was consistent across all domains measuring male sexual function with a dose-response relationship. The large magnitude of the observed effect combined with its consistency across all measures of sexual dysfunction support a possible underlying association. While the results need to be replicated in other studies, our findings provide the first piece of evidence that exposure to BPA may have an adverse effect on male sexual functioning in the human population. This finding not only has public health implications for male fertility, but possibly for other health outcomes as well, since male sexual function may be a more sensitive and easily measured endpoint that provides early signals about the adverse BPA effects on other endpoints that are more difficult to study. On the other hand, it should be noted that the observed association may only apply to highly exposed workers and a similar effect in environmentally exposed lower dose remains unclear. Nevertheless, given the widespread exposure to BPA by the human population, this finding increases the need to examine the health effects of BPA in both occupationally and environmentally exposed populations.

\section{Authors' Role}

D.-K.L. is the Principal Investigator of the study and was responsible for the overall study design, obtaining funding, supervising data collection, directing data analyses, interpreting results and preparing manuscript. Z.Z. was responsible for designing and supervising BPA measurement. D.Q. and M.M. were involved in data collection and data analyses, Y.H. and T.W. were involved in conduct of BPA measurement. J.W. and Q.Z. were involved in data collection. X.W. and J.F. were involved in data analyses. L.H. was involved in study design and obtaining funding. H.C. was also involved in the study design and obtaining funding. E.G., site-Principal Investigator in China, was involved in the study design and data analyses. W.Y. was responsible for data collection and involved in study design, data analyses and interpretation of the results.

\section{Acknowledgement}

We would like to thank Roxana Odouli for her help in developing data collection instruments and preparing the manuscript; the participating factories for their cooperation; and staff at local Chinese Centers for Disease Control for their help with data collection.

\section{Funding}

This study was supported by a grant from the US National Institute of Occupational Safety and Health (NIOSH) (ROI OH007580). 


\section{References}

kingbemi BT, Sottas CM, Koulova Al, Klinefelter GR, Hardy MP. Inhibition of testicular steroidogenesis by the xenestrogen bisphenol $A$ is associated with reduced pituitary luteinizing hormone secretion and decreased steroidogenic enzyme gene expression in rat Leydig cells. Endocrinology 2004; | 45:592-603.

Bonefeld-Jorgensen EC, Long M, Hofmeister MV, Vinggaard AM. Endocrine-disrupting potential of bisphenol $A$, bisphenol $A$ dimethacrylate, 4-n-nonylphenol, and 4-n-octylphenol in vitro: new data and a brief review. Environ Health Perspect 2007; I I 5(Suppl. I):69-76.

Calafat AM, Kuklenyik Z, Reidy JA, Caudill SP, Ekong J, Needham LL. Urinary concentrations of bisphenol $\mathrm{A}$ and 4-nonylphenol in a human reference population. Environ Health Perspect 2005; I I 3:39I -395.

Calafat AM, Ye X, Wong LY, Reidy JA, Needham LL. Exposure of the U.S. population to bisphenol A and 4-tertiary-octylphenol: 2003-2004. Environ Health Perspect 2008; 1 16:39-44.

Carwile JL, Luu HT, Bassett LS, Driscoll DA, Yuan C, Chang JY, Ye X, Calafat AM, Michels KB. Polycarbonate bottle use and urinary bisphenol A concentrations. Environ Health Perspect 2009; I I 7:1368-1372.

Della SD, Minder I, Belloni $\vee$, Aloisi AM, Dessi-Fulgheri F, Farabollini F. Pubertal exposure to estrogenic chemicals affects behavior in juvenile and adult male rats. Horm Behav 2006;50:30 I-307.

Dodds EC, Lawson W. Molecular structure in relation to estrogenic activity. Compounds without a phenanthrene nucleus. Proc $R$ Soc 1938; 1 25:222-232.

Farabollini F, Porrini S, Della SD, Bianchi F, Dessi-Fulgheri F. Effects of perinatal exposure to bisphenol $A$ on sociosexual behavior of female and male rats. Environ Health Perspect 2002; I I 0(Suppl. 3):409-4I4.

Giusti RM, Iwamoto K, Hatch EE. Diethylstilbestrol revisited: a review of the long-term health effects. Ann Intern Med 1995; I 22:778-788.

Kim YH, Kim CS, Park S, Han SY, Pyo MY, Yang M. Gender differences in the levels of bisphenol A metabolites in urine. Biochem Biophys Res Commun 2003;3 I 2:44 I-448.

H, Verloop ], Kaster ME, Burger CW, van Leeuwen FE. Hypospadias in sons of women exposed to diethylstilbestrol in utero: a cohort study. Lancet 2002;359: I 102- I I07.

Kuehn BM. Expert panels weigh bisphenol-A risks. J Am Med Assoc 2007; 298: | 499- 1503 .

Lee HJ, Chattopadhyay S, Gong EY, Ahn RS, Lee K. Antiandrogenic effects of bisphenol $A$ and nonylphenol on the function of androgen receptor. Toxicol Sci 2003;75:40-46.

Matsumoto A, Kunugita N, Kitagawa K, Isse T, Oyama T, Foureman GL, Morita M, Kawamoto T. Bisphenol A levels in human urine. Environ Health Perspect 2003; I I I: I0I-104.

Miyamoto K, Kotake M. Estimation of daily bisphenol a intake of Japanese individuals with emphasis on uncertainty and variability. Environ Sci 2006; I3:15-29.

Myers JP, vom Saal FS, Akingbemi BT, Arizono K, Belcher S, Colborn T, Chahoud I, Crain DA, Farabollini F, Guillette LJ Jr et al. Why public health agencies cannot depend on good laboratory practices as a criterion for selecting data: the case of bisphenol A. Environ Health Perspect 2009; I | 7:309-315.

National Toxicology Program, U.S. Department of Health and Human Services. NTP-CERHR Monograph on the Potential Human
Reproductive and Developmental Effects of Bisphenol A. September, 970 2008.

O'Leary MP, Fowler FJ, Lenderking WR, Barber B, Sagnier PP, Guess HA, Barry MJ. A brief male sexual function inventory for urology. Urology 1995;46:697-706.

Palmer JR, Wise LA, Hatch EE, Troisi R, Titus-Ernstoff L, Strohsnitter W, Kaufman R, Herbst AL, Noller KL, Hyer $M$ et al. Prenatal diethylstilbestrol exposure and risk of breast cancer. Cancer Epidemiol Biomarkers Prev 2006; I5: I509-15|4.

Richter CA, Birnbaum LS, Farabollini F, Newbold RR, Rubin BS, Talsness CE, Vandenbergh JG, Walser-Kuntz DR, vom Saal FS. In vivo effects of bisphenol A in laboratory rodent studies. Reprod Toxicol 980 2007; 24:199-224

Rosen RC, Riley A, Wagner G, Osterloh IH, Kirkpatrick J, Mishra A. The international index of erectile function (IIEF): a multidimensional scale for assessment of erectile dysfunction. Urology 1997;49:822-830.

Sohoni P, Sumpter JP. Several environmental estrogens are also 985 anti-androgens. J Endocrinol 1998; 158:327-339.

Sun H, Xu LC, Chen JF, Song L, Wang XR. Effect of bisphenol A, tetrachlorobisphenol $\mathrm{A}$ and pentachlorophenol on the transcriptional activities of androgen receptor-mediated reporter gene. Food Chem Toxicol 2006;44:1916-1921.

Swan SH. Intrauterine exposure to diethylstilbestrol: long-term effects in 990 humans. APMIS 2000; 108:793-804.

Troisi R, Hatch EE, Titus-Ernstoff L, Hyer M, Palmer JR, Robboy SJ, Strohsnitter WC, Kaufman R, Herbst AL, Hoover RN. Cancer risk in women prenatally exposed to diethylstilbestrol. Int J Cancer 2007; I 21:356-360

Tyl RW, Myers CB, Marr MC, Thomas BF, Keimowitz AR, Brine DR, Veselica MM, Fail PA, Chang TY, Seely JC et al. Three-generation reproductive toxicity study of dietary bisphenol A in CD SpragueDawley rats. Toxicol Sci 2002;68: I2I - I46.

Tyl RW, Myers CB, Marr MC, Sloan CS, Castillo NP, Veselica MM, Seely JC, Dimond SS, Van Miller JP, Shiotsuka RN et al. 1000 Two-generation reproductive toxicity study of dietary bisphenol $A$ in CD-I (Swiss) mice. Toxicol Sci 2008a; 104:362-384

Tyl RW, Myers CB, Marr MC, Sloan CS, Castillo NP, Veselica MM, Seely JC, Dimond SS, Van Miller JP, Shiotsuka RS et al. Two-generation reproductive toxicity evaluation of dietary 1005 I 7beta-estradiol (E2; CAS No. 50-28-2) in CD-I (Swiss) mice. Toxicol Sci 2008b; 102:392-4I2.

vom Saal FS, Akingbemi BT, Belcher SM, Birnbaum LS, Crain DA, Eriksen M, Farabollini F, Guillette LJ Jr, Hauser R, Heindel JJ et al. Chapel Hill bisphenol A expert panel consensus statement: integration of mechanisms, effects in animals and potential to impact human 1010 health at current levels of exposure. Reprod Toxicol 2007;24:131-138.

Wetherill YB, Akingbemi BT, Kanno J, McLachlan JA, Nadal A, Sonnenschein C, Watson CS, Zoeller RT, Belcher SM. In vitro molecular mechanisms of bisphenol A action. Reprod Toxicol 2007; 24: $178-198$.

Xu LC, Sun $H$, Chen JF, Bian Q, Qian J, Song L, Wang XR. Evaluation of androgen receptor transcriptional activities of bisphenol A, octylphenol and nonylphenol in vitro. Toxicology 2005;2 16: I97-203.

Submitted on April 9, 2009; resubmitted on September 9, 2009; accepted on September 16, 2009 